\title{
Critical theory and the implementation of lifelong learning in Vietnam
}

\author{
Phan Thi Tra Khuc ${ }^{1 *}$ \\ ${ }^{1}$ The University of Da Nang, Vietnam \\ *Corresponding author: khuc.phan@vnuk.edu.vn
}

\begin{tabular}{|c|c|}
\hline ARTICLE INFO & ABSTRACT \\
\hline $\begin{array}{l}\text { DOI: } 10.46223 / \mathrm{HCMCOUJS} . \\
\text { soci.en.9.2.258.2019 }\end{array}$ & $\begin{array}{l}\text { Lifelong learning is the continuous acquisition of } \\
\text { knowledge and skills which occurs throughout life with an } \\
\text { emphasis on the full development of personality. Despite the } \\
\text { increasing interest of Vietnamese policy makers in promoting }\end{array}$ \\
\hline Received: October 23 $3^{\text {rd }}, 2019$ & lifelong learning, the implementation of lifelong learning at \\
\hline Revised: December 9 $9^{\text {th }}, 2019$ & universities is still limited. This research delineated and \\
\hline Accepted: December $13^{\text {th }}, 2019$ & $\begin{array}{l}\text { critiqued the policies and the current practices of lifelong } \\
\text { learning at the college level of the Ministry of Education and } \\
\text { Training in Vietnam (MOET) under the perspective of critical } \\
\text { theory. From the discussion of the policies and practices that the }\end{array}$ \\
\hline Keywords: & $\begin{array}{l}\text { MOET was implementing, recommendations for the policy } \\
\text { makers were made with the aim of helping Vietnamese students }\end{array}$ \\
\hline $\begin{array}{l}\text { critical theory, lifelong learning, } \\
\text { Vietnam education }\end{array}$ & $\begin{array}{l}\text { embrace their right to lifelong learning and fulfill the personal } \\
\text { and democratic purpose of education. }\end{array}$ \\
\hline
\end{tabular}

\section{Introduction}

The notion of lifelong learning has been around for decades. It literally means that learning is pursued at all stages throughout the lifetime from schools to work, from home to society. In the 21 st century, where information proliferates and innovations permeate the community, lifelong learning becomes an indispensable skill to help people become wellprepared and be able to face different current and emerging challenges. In addition, globalization has transmitted the flow of new information through the boundaries of countries and made knowledge accessible in nearly every corner of the world. This era of knowledge explosion makes it imperative for people to engage in lifelong learning in order to stay current.

\subsection{Form of the research}

Colleges play a particularly strong role in helping Vietnam boost its economy when Vietnam aims to "improve the quality of human resources in all sectors so that it may claim a well-trained workforce among its competitive advantages" (Muller-Marin, 2010, p. 29). As a result, Vietnam Government has formalized its commitment to lifelong learning with considerable attention to the college level. However, despite the increasing interest in and numerous discussions on this topic, the implementation of lifelong learning at universities in 
Vietnam is still limited (D. N. Pham, 2014). Therefore, this project aims to investigate how to encourage lifelong learning at the college level in Vietnam.

To this end, this project delineates the policies and the current practices that MOET has established to illustrate their commitment to the philosophy of lifelong learning. Based on a review of literature about different discourses on lifelong learning, the position of lifelong learning that the MOET is following will be analyzed. This position will be critiqued from the perspective of critical theory. Critical theory is employed in the analysis because it raises fundamental questions about educational objectives, knowledge and the exercise of power (Brookfield, 2005). These questions need to be addressed in the discussion of policies on lifelong learning as policies and curricula are documents legitimized by the dominant forces, which shape the climate of lifelong learning within which people study and live. In the Vietnamese context where the policy-making is under the top-down power structure and people in lower levels are not encouraged and not into the habit of raising their voices, the discussion of power is even more pressing to ensure people's democratic rights. In addition, since the educational system in Vietnam places a heavy emphasis on passing examinations and getting degrees, educational objectives in this context need revisiting to help people come closer to the goal of emancipation in education. From the discussion of the policies and practices that the MOET is implementing, recommendations for the policy makers will be made with the aim of helping students embrace their right to lifelong learning and fulfilling the personal and democratic purpose of education.

\subsection{Historical and cultural contexts}

Confucian educational ideals were introduced in Vietnam in the first century B.C. by the Chinese invaders. Confucian philosophy emphasizes the importance of hierarchy in human relationships and he insists that there must be a leader in any hierarchical environment to make the society stable (Fielding, 1997). Confucius also proposes the idea of creating "harmony" in a society. By harmony, he means everyone needs to respect different opinions and work with other people harmoniously. In his Analects, Confucius advises people to harmonize but not to seek sameness because a government consisting of one voice is as dangerous and boring as a symphony composed of one instrument (Li, 2006).

Unfortunately, this concept of "harmony" is interpreted in Vietnamese education as obeying the authority of their teachers without questioning. Influenced by this line of thinking for a long time, Vietnamese teachers often regard students as passive recipients and believe it is their job to imprint knowledge and moral values on them. This belief is consistent with behaviorism theory, which posits students are blank slates (Oakes, Lipton, Anderson, \& Stillman, 2013). According to this learning theory, all learning is how people react to external stimuli and these behaviors can be shaped through positive reinforcement or punishment. The alignment in the philosophy of behaviorism with the modern-day Confucianism can be a partial explanation for the continuing existence of this teaching approach in the educational system in Vietnam.

With the influence of the Confucian philosophy of education and the behaviorist teaching approach, Vietnamese teachers often teach students what to think rather than how to think (Hamano, 2009). They usually dismiss the students' opinions, not giving them much chance to express themselves, which seriously hinders students' thinking and their learning 
autonomy. However, Littlewood (2000) suggests that the lack of Asian students' responsibility for their learning is "more likely to be a consequence of the educational contexts that have been or are now provided for them, than of any inherent dispositions of the students themselves" ( $\mathrm{p}$. 33). This idea portrays Vietnamese learners as ones who do not wish to be spooned with facts, and as stated in Littlewood's study, they do not regard teachers as the ones who should not be questioned. They still want to explore knowledge by themselves, and they are eager to take the role of active learners if they are trained to do so.

\subsection{Social contexts}

Globalization is affecting every corner of the world and Vietnam is not immune from this trend. Globalization brings more opportunities for people to compete with their global peers. The effect of globalization is far-reaching and not limited to economic fields. Education also receives a huge impact as globalization makes the learning of new skills and knowledge increasingly important for people to secure their competitiveness. Each country has its own way to adapt to the challenges as well as the possibilities posed by globalization. The MOET has implemented several policies to enhance and maintain the competitive edge of its citizens in the global market in acknowledgment of the call of globalization.

One of the policies that have created a dramatic impact on the educational system in Vietnam is "Đổi Mới” (i.e., Renovation), the economic reforms in Vietnam in 1986 (Tran et al., 2016). Before "Đổi Mới", Vietnam had run a closed-door economy with the Soviet-styled central planning economic model. At that time, all universities in the country were considered the public good and funded by the Government, which made the state budget carry a huge burden in coping with the dramatic expansion of higher education. Under "Đổi Mới” policy, the Government has abandoned its monopoly in many aspects including allowing the involvement of private sectors in education and training, which leads to the appearance of private universities in Vietnam. The increasing participation of Vietnam in the global economy also made the Government revisit the structure of education and regard the privatization of educational institutions as an instrument of economic policies (H. T. Nguyen, 2007).

Vietnam is also moving toward lifelong learning and the Vietnam government has made a commitment to build a lifelong learning society through the approval of the scheme on "the Building a Learning Society National Framework" for the period of 2005-2010 and recently for 2012-2020. To accomplish this national goal, the Government has launched a number of initiatives including establishing community learning centers, choosing an annual national "Book day", organizing "Book week" events, organizing seminars on lifelong learning, and officially including "continuing education" into the educational system, etc. As a result, more than 11,900 community learning centers have been established since 2005 (Hossain, 2016) with the aim to empower individuals, especially out-of-school youth and adults, through lifelong learning opportunities; Lifelong Learning Forum was organized in 2010 to design local and national lifelong learning strategies; a Regional Center for Lifelong Learning was set up in 2011 with a concentration on research and consultancy on lifelong learning. The Vietnam government also aims to implement lifelong learning activities in libraries, museums, cultural centers, and clubs. In general, these projects have achieved certain progress in raising awareness among Vietnamese people of this learning philosophy, broadening the scope of education, and promoting the reading culture, an important step to create a lifelong learning society. 
However, in Vietnam, lifelong learning is still a vague concept as this notion has not yet been clearly defined (D. N. Pham, 2014). Although great efforts have been made in transforming a passive learning approach to an active, learner-centered one, Vietnamese schools are mostly aiming at exam preparation and degree attainment. This kind of education is ill-suited to provide people with the skills they need and to prepare them for becoming lifelong learners. In addition, continuing education, an organic component of the national educational system, has a bad reputation in Vietnam and it is not associated with lifelong learning as expected by the Government. It is implicitly regarded either as a kind of complementary education reserved for illiterate and disadvantaged children or a place to easily get a certificate or degree necessary for career promotion (D. N. Pham, 2014). In general, initiatives for lifelong learning of the Government mostly focus on campaigns to promote lifelong learning, not yet instill this philosophy into practices.

\section{Literature review}

\subsection{Lifelong learning}

Lifelong learning is a rather elusive concept as it means different things to different people. Generally, the contemporary discourse of lifelong learning is divided into two paradigms: the humanistic and the capitalistic ones. These two paradigms not only show different approaches but also represent discrepancy in emphasis and priorities in the practices of lifelong learning.

The first paradigm, which is guided by a humanistic view, is captured in the 1972 UNESCO report with the title: "Learning to be: the world of education today and tomorrow." This report makes a persuasive case for lifelong learning and underscores that education must be conceived of as a constant process that helps people fulfill themselves through communicating and questioning the world (Faure et al., 1972). This report also strongly asserts that lifelong education must be seen as a personal good and everyone must be given a chance to enjoy their "democratic rights to participate in the management of their educational establishment" (Faure et al., 1972, p. 78). Following this view, other educators also contend that the goal of education is to enable people to be themselves, gain personal freedom, manage their own lives, improve their capabilities, and actively interact with uncertain or dislocated contexts (Biesta, 2006; Brodbelt, 1983; Walker, 2012). Similarly, Barnett (2006) emphasizes self-development by arguing that lifelong learning is "a matter of continually engaging in forming a sense of oneself in the world" (p. 63).

The second paradigm of lifelong learning is strongly affected by the economic imperative. It is guided by the human capital theory which considers lifelong learning as a means to promote employability and achieve economic prosperity of individuals and society (Biesta, 2006; Brodbelt, 1983; Rubenson, 2011). In this capitalistic approach, the purpose of learning is to adapt to the changing demands of the global market in the globalization era when knowledge and skills become increasingly important for a country to secure its competitiveness and economic growth. This view of lifelong learning is adopted by many transnational organizations such as OECD, EU, and the World Bank. OECD has proclaimed that investment in lifelong learning is inevitable for "keeping up with technological change and maintaining competitiveness" (Rubenson, 2011, p. 413). Similarly, the European Union has also perceived lifelong learning as a tool for "individual citizens to participate fully in society and to strengthen European competitiveness and economic growth" (Van der Pas, 2001, p. 11). This view of 
lifelong learning is also echoed in the World Bank (2003)'s report when this organization asserts that lifelong learning is "education for the knowledge economy" (p. xiii).

While the first paradigm perceives lifelong learning as "learning to be", the second paradigm sees lifelong learning as "learning to be employable". Globalization has created tough competition in global markets, and this makes a number of countries decide to invest in human capital in order to have a high-skilled workforce. As a result, human capital becomes the purpose of lifelong learning. The transformation in the purpose of education starts from the assumption that lifelong learning is an instrument for economic-related goals. In addition, lifelong learning is transformed from individuals' choice into an obligation for them to compete with their peers and stay current.

These two paradigms are closely reflected in the three functions of lifelong learning that Aspin and Chapman (2001) propose: lifelong learning for economic progress and development, lifelong learning for personal development and fulfillment, and lifelong learning for social inclusiveness and democratic understanding and activity. In alignment with these functions, Biesta (2006) also claims that lifelong learning has three dimensions: economic, personal and democratic. The economic dimension of lifelong learning refers to the continuous acquisition of knowledge and skills to ensure the employability and economic growth of the society. The personal dimension of lifelong learning focuses on enabling human beings to live successfully in the uncertain and unpredictable world through continuous learning from experiences they encounter in their lives. The third dimension of lifelong learning, the democratic one, revolves around democracy which aims to empower human beings to live with others in a more democratic and inclusive way. While the economic dimension cannot be avoided in the face of globalization, personal and democratic dimensions play an important role in ensuring the right of human beings to live their own lives.

According to Aspin and Chapman, the goal of lifelong learning should not center only on economic prosperity but on personal and democratic fulfillment as well. They argue that lifelong learning is a complex process; it should be considered an inter-play between the three functions or dimensions mentioned above. In other words, human beings should have freedom of choices and opportunities to do what they want to do, to become what they value and to live in harmony and democracy with others. These opportunities may include but are not limited to work opportunities. Education should aim at creating a skilled workforce and at the same time ensuring democracy and more rewarding life for human beings. Therefore, these three functions of lifelong learning should be considered when the policy makers of any countries or any institutions formulate the policies and practices to promote lifelong learning.

\subsection{Critical theory}

Critical theory emerges from the educational reforms initiated by a group of scholars, the Frankfurt School, in Germany under the belief that the world is characterized by inequities and systemic exploitation of the privileged group (Brookfield, 2005). In this world view, the rights of oppressed groups are trampled and their human rights are violated. This theory addresses a wide range of topics from power dynamics, the practice of oppression, the use of micro-aggressions to the production of a social character of capitalism (Brookfield, 2005). To provide a critical re-examination and re-assessment of the issues of educational equity, this theory was employed and developed by other philosophers and educationalists including Foucault, Freire, Giroux, and Apple, etc. With the aim of discussing and analyzing the policies 
of lifelong learning, this paper will review the two big ideas of the critical theory: power and ideology or power and knowledge as proposed by Foucault (1980) as these constructs are related to the issues of control and oppression with respect to lifelong learning policies.

According to Foucault, power is evident in human existence. The dominant group uses its power to inscribe certain practices with particular kinds of meaning and disseminate the dominant ideology to maintain structural inequality (Brookfield, 2005; Usher \& Edwards, 2007). Therefore, ideology is seen as common sense to support the interests and objectives of the ruling group. Through language, social habits, and cultural forms, the dominant group manipulates ideology and distorts the way the majority of people think about the world by persuading them that the way the world is being organized is logical (Brookfield, 2005; Fromm, 1968). Knowledge is neither neutral nor objective; it is socially constructed and infused with ideology and it reflects the value of those who produce it (Sensoy \& DiAngelo, 2012). Therefore, it can be concluded that knowledge is an exercise of power and at the same time knowledge also engenders power. The constructs of power and knowledge work symbiotically; they entwine to create regimes of truth, the dominant sets of ideas and beliefs that frame how people make sense of their experiences (Foucault, 1980).

Since knowledge is a social construct, it is facile to believe that schools disseminate knowledge in a neutral and objective manner. The traditional view of education works under the assumption that teachers are pillars of knowledge and students are empty vessels for teachers to imprint knowledge and values on. Teachers possess the authority to decide which knowledge to teach and students, as passive knowledge receivers, comply with it. This classroom discourse clearly shows the power relation as there is a clear division of the oppressed-teachers, and the oppressors-students. This banking model of education is strongly rejected by Freire (1970) as this perpetuates the oppression and works against emancipation. As a result, he suggests a problem-posing education as an alternative to the banking model in which both teachers and students are subjects in exercising their own power. In other words, in the educational process, teachers are expected to wield their power through uncovering reality and creating knowledge of the world while students develop their power to critically reflect on the way they exist in the world (Freire, 1970).

Regarding lifelong learning, Freire posits that education must help students acknowledge themselves as "beings in the process of becoming" (Freire, 1970, p. 84). Being aware of their unfinished character, they will follow the ongoing process of education. In order to achieve this aim, students must be given a chance to develop their own agency about what and how they want to study and act on those choices with an understanding of situational constraints (Giroux, 1988). To put it another way, students are not expected to obey power and authority but constantly negotiate and debate on knowledge and meanings that are transmitted from the dominant forces in education, i.e., policy makers in education, curriculum designers and teachers, etc. Inconsistent with Dewey's philosophy of education, critical theorists conclude that it is the role of schools to help students perceive dominant ideology, empower them to challenge educational inequities and raise their voice for a more just and democratic society (Aliakbari \& Faraji, 2011; Giroux, 1988).

The long-term impact of modern-day Confucianism which favours the hierarchy and knowledge transfer method in education is the main reason for the use of critical theory in the analysis of this paper. The hierarchy with the top-down power structure in Vietnamese society expects people in lower levels to act upon their higher counterparts' requests (T. N. T. Pham \& 
Hoang, 2018). Thus, in a classroom setting, teachers are presumed to have supreme authority and students are expected to obey them without resistance. Students are also not encouraged to embrace their democratic rights by raising their voices about any issues. In addition, the knowledge transfer teaching method turns students, who are supposed to be creators of knowledge, into passive knowledge receivers (Littlewood, 2000). This makes both teachers and students have misconceptions about their roles in the classroom. As a result, many Vietnamese students are confused when they are empowered to negotiate knowledge and develop the agency of their learning as they are not familiar with advocating for themselves and others. For this reason, critical theory aims to help both the oppressed and the oppressors in this setting to become aware of how power is exercised, how oppression is created and then find ways to resist them.

\section{Analysis of the government's policies and practices}

Vietnam is moving toward the emerging trend of lifelong learning and the Vietnam government has formalized its commitment to lifelong learning through several major policies. In addition, a number of conferences and discussions have been conducted with the aim of helping the Government further clarify the concept of lifelong learning and develop a suitable road map in response to the call of this rapidly changing world. Working in close collaboration with UNESCO, the Vietnam Ministry of Education and Training has finalized four fundamental goals for lifelong learning in Vietnam: to know and to be, to acquire a profession and secure a job, to make oneself and others happy, and to contribute to the development of the country and mankind (Decision No.89/2013/QĐ-TTG). These goals reflect all three dimensions of lifelong learning: personal, democratic and economic as stated by Biesta (2006). However, there exist huge discrepancies between the goals of lifelong learning and how the Government puts them into practice.

First, in spite of tremendous efforts that have been invested in building a learning society, the Vietnam government has not succeeded in implementing this pragmatic approach to promote lifelong learning. In 2005, the MOET approved the scheme on "the Building a Learning Society National Framework" for the period of 2005-2010 and in 2012, this project was extended until 2020. The Prime Minister states that the goal of a learning society is to "create good opportunities and favorable conditions for everybody [...] to pursue learning constantly and continually" (Decision No.112/2005/QĐ-TTG). When all citizens are provided continuous learning opportunities in a learning society, their capacity will be increased and as a result, the quality of human resources will be enhanced.

Under the model of a learning society, there is a gradual shift toward open and distance education, a learning network which offers flexibility in both learning and practice modalities to meet the demands of a diverse population and ensure social equality in education. To date, there are two open universities and more than 17 other universities offering open and distance education services in Vietnam which provide maximum opportunities for anyone who wants to study (T. K. Nguyen, 2011). Many colleges have invested in enhancing distance educational technologies as well.

However, graduates from these programs are not valued as a number of companies and even governmental organizations claim to recruit graduates from the mainstream programs only. One of the reasons for this lies in the fact that the quality of the outputs from these 
programs is not equivalent to graduates from the mainstream ones. When operating open and distance education, many colleges do not sort out students frequently and do not invest in recruiting well-trained teachers for the programs (M. H. Nguyen, 2016). Courses in the open universities are no longer offered based on the needs of the learners but on the assignment of the MOET instead. These open college programs gradually abandon their initial philosophy and belief that each individual is an active, intellectual agent and they all should be given a chance for higher education to ensure educational justice.

In building a learning society with flexible learning programs to promote lifelong learning, a number of continuing education institutions have also been established throughout the countries. In 2013, Vietnam has 70 provincial and 642 district level continuing education centers. These centers are claimed to perform the duties of providing illiteracy eradication and post-literacy courses, initial training in foreign languages and IT, thematic courses to update knowledge, skills and technology, and short-term vocational training courses (Decision No.01/2007/QĐ-BGDĐT). Article 44 of the 2005 Law on Education states that the goals of these centers are to help people pursue continuous and lifelong learning for personal fulfillment, broaden their knowledge, gain qualifications to increase life quality, find jobs, and adapt to the social life. As such, the operation of continuing education centers can ensure the right to education for all citizens in society.

However, although the continuing education centers are supposed to have many functions, many centers just perform the only function of organizing post-literacy courses, specifically high school courses because of the limitation of the infrastructure and outdated teaching equipment. These programs are home to high school students who cannot pass the entry test to public high schools or who want to get the diploma degree but study fewer subjects so that they can have more time to prepare for the national entrance examination to university (Duong, 2015). The reality of these centers does not follow the initial vision pertaining to lifelong learning that the Government promotes. In addition, the Vietnam Law on Education stipulates that the national educational system consists of formal education and continuing education (Decision No.38/2005/QH11). As such, continuing education is implicitly understood as the non-formal one, outside the remit of schools; thus, it does not receive enough attention and interest from the public.

Second, although the MOET's goals of lifelong learning cover all three functions of lifelong learning, in practice, the personal and democratic functions seem to be subordinate to the economic one. While the commitment is strong, as discussed above, there is still a long way for the MOET to go to fulfill the vision of building a learning society which helps people improve their life quality for personal and democratic fulfillment. In addition, the other policies that have been carried out these days by the MOET communicate a different vision of lifelong learning, which is shaped by economic considerations. In the discourse presented through these policies, the main function of lifelong learning is to remain productive and employable in response to the demands of the global economy.

The first policy that needs to be mentioned in the Vietnam Higher Education Reform Agenda, a major reform presenting a vision for higher education in Vietnam approved by the Vietnam government. This reform agenda states that by 2020, the higher education system will be "advanced by international standard, highly competitive, and appropriate to the socialist- 
oriented market mechanism" in order to meet "the demands of industrialization, modernization, global economic integration and society's demand for learning opportunities" (T. N. Pham, 2010, p. 51). This statement starts from the assumption that satisfying economic demands is the main role of higher education. This agenda requires colleges to consider its curricula to adapt to the changing economic market and focus on efficiency, accountability, accreditation and international competitiveness. Course offerings at colleges become more responsive to marketbased pressures. It is logical to assume that this reform highlights the instrumental purposes, education for employability, of higher education.

From the viewpoint of education as an investment, the MOET also launched a huge project named the National Foreign Languages 2020 Project in 2008 and extended it to 2025 (2025 Project) to increase Vietnamese people's foreign language proficiency. The prominence of the English language has been increasing in the current era of globalization and integration, when the enlargement of corporations in all fields goes beyond national boundaries. In the Vietnamese context, becoming a member of the World Trade Organization and ASEAN Economic Community has provided Vietnamese people with the opportunity to compete in global markets; therefore, English is considered an essential tool to connect this developing country with the open world and the global economy. Consequently, the 2025 Project has been undertaken with the goal:

Renovate foreign languages education in the national education system, continue to implement new foreign languages programs at all levels, enhance learners' foreign language competence to meet the demand of study and work, strengthen the competitive edge of human resources in the era of integration, contributing to the country development, establish a nationwide foreign languages foundation for general education in 2015 (Decision No.2080/2017/ QĐ-TTG).

Although the 2025 Project covers all foreign languages, it puts an emphasis on English. This project has made an enormous investment in establishing the English language proficiency framework in Vietnam and using this framework to assess the English proficiency of teachers and students of all levels. English has been chosen to be a compulsory subject since elementary schools to colleges and a compulsory subject in every graduation examination, including the exit exam for graduate and post-graduate programs of all majors. This project also aims at enhancing the quality of teaching and learning English including organizing workshops on teaching methodology for teachers and teacher trainers, organizing English courses for teachers whose English proficiency has not met the requirements of the MOET, and relocating teachers if they fail the proficiency test after they take the English course, etc. The reform agenda as well as the 2025 Project show a high correlation between the MOET's vision on education and the national labor productivity.

There exists a mismatch between the MOET's policies on lifelong learning and other educational policies that have been implementing by the MOET at the same time. While the MOET affirms its commitment to three functions of lifelong learning, other policies give priority to the economic imperative in this globalized knowledge economy and set employability as the most important educational goal. These policies focus on meeting the needs of the economy, increasing the citizens' economic potential and thus neglecting lifelong learning opportunities for personal and democratic fulfillment. 
The fact that the discourse of lifelong learning in Vietnam makes a focus on economic function distorts the aim of education that Dewey (1916), Freire (1970), Giroux (1988) and Faure et al. (1972) propose when it does not help students to develop for their personal good and inspire them to work toward freedom, justice and democracy. In the UNESCO report, Faure et al. (1972) further underscore that "learning to be" is the aim of education; however, people cannot develop their identity as persons without other citizens of communities. Therefore, "learning to be" must be understood as "learning to be with others" and lifelong learning must attach its intrinsic value to democracy. A focus on economic growth shifts its function from an instrumental tool into the ultimate goal of lifelong learning. As a result, students are compelled to improve the knowledge and skills of the world of work and they are not encouraged to choose what to learn based on their own interests. If their knowledge is not compatible with the demand of the market, it is not valued and discarded. Students are positioned as human resources to be developed through lifelong learning (Jarvis, 2000), not those who are supported to learn with lifelong learning opportunities.

In the UNESCO report on lifelong learning, Medel-Anonuevo, Ohsako and Mauch (2001) emphasize that education is a basic human right of individuals; therefore, the policy makers in education must fulfill the duty to create favorable conditions such as resources and opportunities for students to learn. However, with the 2025 Project, the MOET presses the demand of the English language to face the wave of globalization on both teachers and students and uses it as a tool to relocate teachers and fail students from getting their major degrees. This shifts the responsibility of policy makers from supporting people's learning into forcing them to learn the knowledge and skills desirable by the market. This also shifts the right to learn of each individual into the responsibility to follow the demand and obey the supreme authority of the dominant forces. This oppression prevents people from embracing their democratic rights and achieving emancipation (Freire, 1970). The Prime Minister also emphasizes the shift of learning from individuals' rights into their responsibilities when he declares that every person and every organization must share the "responsibility and duty of studying and actively participating in building up the learning society" (Decision No. 112/2005/QĐ-TTG). When lifelong learning is no longer an option but the responsibility that every individual needs to carry to stay current, people will not be seen as victims but the agents to blame for if they fail to overcome the barriers to participate in the economic environment.

Setting economic reasons to be the main driver for lifelong learning not only violates the right to education of individuals but also negatively affects their motivation to learn as well. Ryan and Deci (2000) underline that it is the intrinsic motivation, the motivation of doing something that is inherently interesting or enjoyable, which leads to high-quality learning and creativity, not the extrinsic motivation, which is manipulated by satisfying consequences outside of a person such as economic benefits. In the discourse of lifelong learning in Vietnam, the motivation for learning does not primarily derive from the love of learning for its own sake; consequently; it cannot generate the highest quality of learning among learners. According to Faure et al. (1972), the configuration for lifelong learning which is not set by individuals but other forces such as the control of the policy makers or the demand of the market is also "unable to ensure true democratization' (p. xxix). 


\section{Recommendations}

Globalization gives Vietnamese people the opportunity to compete with global markets, but at the same time, it puts pressure on the educational system to keep up with the market demand for qualified workers. As a result, the Vietnam government shows its heavy focus on the economic dimension of lifelong learning through the implementation of its policies and lets the market shape the practices and the agenda for lifelong learning in Vietnam. This distorts the aim of education, the rights and the motivation of individuals to learn. Therefore, although it is unavoidable for the policy makers to regard education as a factor to ensure its economic advantage, it is also necessary for them to balance an instrumental role of lifelong learning with the personal and democratic roles.

To date, what the Government means by lifelong learning is not yet clear when it is implementing different policies which communicate different messages about the vision of lifelong learning at the same time. This generates a huge confusion for colleges and other involved organizations and as a result, each educational institution interprets this notion and put it into practice in their own way based on their own understanding and experience. Therefore, in order to achieve the goal of lifelong learning, there is a need to establish the discourse of lifelong learning in the Vietnamese context. Critical theory suggests that the process of forming the discourse must involve all stakeholders, including teachers and students, who are the main agents of the lifelong learning policies, and the policy makers of different levels to ensure their rights to exercise their power.

It is not easy for Vietnamese policy makers to abruptly abandon their ultimate power in the process of formulating policies on lifelong learning. In addition, in a culture where people are not familiar of raising their democratic voices, asking people to join the discussion on setting the agenda for lifelong learning can make them confused and feel reluctant to do. For these reasons, the combination of both top-down and bottom-up participation in the policy making process can work in this context. In other words, the Government can start the process by setting the agenda and then create opportunities for people to negotiate and respond to it in order to get stakeholders' input into decision making before they enact any policies. This way of practice not only allows the government to exercise their power but also creates collaboration between the state and its citizens and empowers the citizens to develop their power and agency.

It is imperative that the Government continues to implement their initiatives for lifelong learning including building a learning society, broadening the open and distance education, and promoting the continuing education system. Open education programs and continuing education centers need more attention and support from the Government in terms of human resources and facilities so that they can effectively perform the function of providing people with various learning opportunities to accommodate the diversity of learning needs. In addition, the development of technology in the globalization era brings an explosion of webinars and massive open online courses, making education happen anywhere and anytime. Thus, the Government needs to integrate these technology-enabled learning tools into traditional programs to create a strong link between formal and non-formal education and gradually change the school-based concept of learning as well as the way people think about education. More campaigns to promote lifelong learning should also be launched to build a culture of learning as a way of living. 
To sum up, higher education in Vietnam still mainly aims to prepare students for their future jobs and solving the national economic problems. It is justifiable to conclude that Vietnamese colleges are not yet places for students to enjoy academic freedom and intellectual development. Although several commitments have been declared on promoting lifelong learning by the Vietnam government, the question about the purpose of education in general and a university itself needs addressing further and the discourse of lifelong learning in the Vietnamese context needs to be reexamined. In addition, more efforts should continue to be invested in order to have their commitments on lifelong learning fulfilled to provide individuals with economic, personal and democratic lifelong learning opportunities.

\section{ACKNOWLEDGEMENTS}

This research is funded by Funds for Science and Technology of the VN-UK Institute for Research and Executive Education, the University of Da Nang under project number T2018-VNUK-04.

\section{References}

Aliakbari, M., \& Faraji, E. (2011). Basic principles of critical pedagogy. In 2nd international conference on humanities, historical and social sciences (pp. 77-85). Singapore: IACSIT Press.

Aspin, D., \& Chapman, J. (2001). Lifelong learning: Concepts, theories and values. SCUTREA 31 st annual conference (pp. 38-41). London, UK: University of East London.

Barnett, R. (2006). Graduate attributes in an age of uncertainty. In P. Hager \& S. Holland (Eds.), Graduate attributes, learning and employability (pp. 49-65). Dordrecht, Netherlands: Springer.

Biesta, G. (2006). What's the point of lifelong learning if lifelong learning has no point? On the democratic deficit of policies for lifelong learning. European Educational Research Journal, 5 (3), 169-180.

Brodbelt, S. (1983). Education as growth: Lifelong learning. The Clearing House, 57 (2), 72-75.

Brookfield, S. (2005). The power of critical theory for adult learning and teaching. New York, NY: Open University Press.

Dewey, J. (1916). Democracy and education: An introduction to the philosophy of education. New York, NY: Macmillan.

Duong, B. (2015). Advantages when pursuing continuing education HCMC journal of education. Retrieved October 20, 2018, from http://www.giaoduc.edu.vn/nhieu-loi-thekhi-hoc-giao-duc-thuong-xuyen.htm

Faure, E., Harrera, F., Kaddoura, A. R., Lopes, H., Petrovsky, A., Rahnema, M., \& Champion, W. F. (1972). Learning to be: The world of education today and tomorrow. Paris, France: UNESCO. 
Fielding, R. (1997). A socio/cognitive perspective on cross cultural attitudes and practices in creativity development. Australian Art Education, 20 (1-2), 27-33.

Foucault, M. (1980). Power/knowledge: Selected interviews and other writings. New York, NY: Pantheon Books.

Freire, P. (1970). Pedagogy of the oppressed. London, UK: The continuum international publishing group.

Fromm, E. (1968). The revolution of hope: Toward a humanized technology. New York, NY: Harper \& Row.

Giroux, H. (1988). Teachers as intellectuals: Toward a critical pedagogy of learning. Westport, CO: Greenwood Publishing Group.

Hamano, T. (2009). Education reform and teacher education in Vietnam. Journal of Education for Teaching, 34(4), 397-410.

Hossain, Z. (2016). Towards a lifelong learning society through reading promotion: Opportunities and challenges for libraries and community learning centers in Vietnam. International Review of Education, 62, 205-219.

Jarvis, P. (2000). Globalization, the learning society and comparative education. Comparative Education, 36 (3), 343-355.

Li, C. (2006). The Confucian ideal of harmony. Philosophy East and West, 56 (4), 583-603.

Littlewood, W. (2000). Do Asian students really want to listen and obey? ELT Journal, 54 (1), 31-36.

Medel-Anonuevo, C., Ohsako, T., \& Mauch, W. (2001). Revisiting lifelong learning for the 21 st century. Hamburg, Germany: UNESCO Institute for Education.

Muller-Marin, K. (2010). Vietnam forum on lifelong learning: Building a learning society. Hanoi, Vietnam: Vietnam News Agency Publishing House.

Nguyen, H. T. (2007). The impact of globalisation on higher education in China and Vietnam: Policies and practices. In 4th Education in a Changing Environment Conference (pp. 1424).

Nguyen, M. H. (2016). Tightening the quality of distance training. Retrieved October 25, 2018, from The Voice of Vietnam website: http://vov.vn/xa-hoi/giao-duc/siet-chat-chat-luongdao-tao-dai-hoc-tu-xa-465029.vov

Nguyen, T. K. (2011). Globalization and higher education in Vietnam. Journal of Interdisciplinary Studies, 23(1), 117-136.

Oakes, J., Lipton, M., Anderson, L., \& Stillman, J. (2013). Teaching to change the world (4th ed.). New York, NY: Paradigm Publishers.

Pham, D. N. (2014). Obstacles to lifelong learning in Vietnam and some suggested solutions. VNU Journal of Education Research, 30(1), 21-30.

Pham, T. N. (2010). The higher education reform agenda: A vision for 2020. In G. Harman, M. Hayden \& T. N. Pham, Reforming higher education in Vietnam: Challenges and priorities (pp. 51-64). London, UK: Springer. 
Pham, T. N. T., \& Hoang, H. (2018). Hierarchy in high school English classroom in Vietnam: Power relationships and learning opportunities. In Identity, equity and social justice in asia pacific education (pp.137-155). Melbourne, Australia: Monash University Publishing.

Rubenson, K. (2011). Lifelong learning: Between humanism and global capitalism. In P. Jarvis (Ed.), The Routledge international handbook of lifelong learning (pp. 411-422). New York, NY: Routledge.

Ryan, R., \& Deci, E. (2000). Self-determination theory and the facilitation of intrinsic motivation, social development, and well-being. American Psychological Association, 55 (1), 68-78.

Sensoy, O., \& DiAngelo, R. (2012). Is everyone really equal? An introduction to key concepts in social justice education. New York, NY: Teachers College Press.

Tran, L., Marginson, S., Do, H., Le, T., Nguyen, N., Vu, T., \& Pham, T. (2016). Higher education in Vietnam: Flexibility, mobility and practicality in the global knowledge economy. Palgrave, UK: Macmillan.

Usher, R., \& Edwards, R. (2007). Lifelong learning - Signs, discourses, practices. Dordrecht, Netherlands: Springer.

Van der Pas, N. (2001). Address by the European commission. In Adult lifelong learning in a Europe of knowledge (pp. 11-18).

Walker, M. (2012). Egalitarian policy formulation in lifelong learning: Two models of lifelong education and social justice for young people in Europe. In D. Aspin, J. Chapman, K. Evans \& R. Bagnall, Second international handbook of lifelong learning (pp. 181-193). Dordrecht, Netherlands: Springer.

World Bank. (2003). Lifelong learning in the global knowledge economy: Challenges for developing countries. Washington, DC: The World Bank. 